\title{
RAR 1 control of mammary gland ductal morphogenesis and wnt1-tumorigenesis
}

\author{
Ellen Cohn, Liliana Ossowski, Silvina Bertran, Christine Marzan, Eduardo F Farias*
}

\begin{abstract}
Introduction: Retinoic acid signaling pathways are disabled in human breast cancer suggesting a controlling role in normal mammary growth that might be lost in tumorigenesis. We tested a single receptor isotype, RAR 1 (retinoic acid receptor isotype alpha, isoform 1), for its role in mouse mammary gland morphogenesis and mouse mammary tumor virus (MMTV)-wingless-related MMTV integration site 1 (wnt1)-induced oncogenesis.

Methods: The role of RAR 1 in mammary morphogenesis was tested in RAR 1 -knockout (KO) mice and in mammary tumorigenesis in bi-genic (RAR $1 /$ KO crossed with MMTV-wnt1) mice. We used whole mounts analysis, stem cells/progenitor quantification, mammary gland repopulation, quantitative polymerase chain reaction (Q-PCR), test of tumor-free survival, tumor fragments and cell transplantation.

Results: In two genetic backgrounds (129/BI-6 and FVB) the neo-natal RAR $1 / \mathrm{KO}-$ mammary epithelial tree was two-fold larger and the pubertal tree had two-fold more branch points and five-fold more mature end buds, a phenotype that was predominantly epithelial cell autonomous. The stem/progenitor compartment of the RAR $\alpha$ 1/ $\mathrm{KO}$ mammary, defined as CD2 $4^{\text {low }} / \mathrm{ALDH}^{\text {high activity }}$ was increased by a median 1.7-fold, but the mammary stem cell (MaSC)-containing compartment, (CD24 ${ }^{\text {low }} / \mathrm{CD} 29^{\text {high }}$ ), was larger (approximately 1.5 -fold) in the wild type (wt)glands, and the mammary repopulating ability of the wt-gland epithelium was approximately two-fold greater. In MMTV-wnt1 transgenic glands the progenitor (CD24 $\left.4^{\text {low }} / \mathrm{ALDH}^{\text {high activity }}\right)$ content was 2.6-fold greater than in the wt and was further increased in the RAR $\alpha 1 / \mathrm{KO}-$ wnt 1 glands. The tumor-free survival of RAR $\alpha 1 / \mathrm{KO}$-wnt1 mice was significantly ( $P=0.0002$, Kaplan Meier) longer, the in vivo growth of RAR $\alpha 1 / \mathrm{KO}$-wnt1 transplanted tumor fragments was significantly $(P=0.01)$ slower and $R A R \alpha 1 /$ KO-wnt1 tumors cell suspension produced tumors after much longer latency.

Conclusions: In vitamin A-replete mice, RAR 1 is required to maintain normal mammary morphogenesis, but paradoxically, also efficient tumorigenesis. While its loss increases the density of the mammary epithelial tree and the content of luminal mammary progenitors, it appears to reduce the size of the MaSC-containing compartment, the mammary repopulating activity, and to delay significantly the MMTV-wnt1-mammary tumorigenesis. Whether the delay in tumorigenesis is solely due to a reduction in wnt 1 target cells or due to additional mechanisms remains to be determined. These results reveal the intricate nature of the retinoid signaling pathways in mammary development and carcinogenesis and suggest that a better understanding will be needed before retinoids can join the armament of effective anti-breast cancer therapies.
\end{abstract}

\section{Introduction}

Retinoic acid receptors (RARs) are the main mediators of the biologic effects of vitamin A, with a long established essential role in the maintenance of the differentiated state of epithelial tissues [1]. More recently, retinoic acid (RA) and other RAR agonists were found

\footnotetext{
* Correspondence: eduardo.farias@mssm.edu

Division of Hematology/Oncology, Tisch Cancer Institute, Mount Sinai School of Medicine, One Gustave L. Levy Place, New York, NY 10029, USA
}

to be growth inhibitory for cancer cell lines in vitro [2-7], in carcinogen-induced rodent mammary cancer models, [8-10] and in xenograft models of human cancer cell [11-13].

Because pharmacological doses of retinoids were used in the carcinogenesis studies, the question of the ability of physiological retinoid levels of vitamin A-replete animals to exert growth suppressive effects and protect epithelia from neoplastic transformation remained 
unanswered. It is, however, well established that the RAR-signaling pathway is defective in carcinomas of several organs, including breast, mostly due to reduced expression of $R A R \beta$ or $C R B P-1[14,15]$. Whether these alterations affect oncogenesis or tumor maintenance, and what might be the mechanism of these effects remains unresolved.

To address the potential role of RAR both in mammary gland morphogenesis and in modifying cancer susceptibility at physiological levels of vitamin-A, we used $R A R \alpha 1$ homozygous null (RAR $\alpha 1 / \mathrm{KO})$ mice and bigenic mice generated by crossing $R A R \alpha 1 / \mathrm{KO}$ with MMTV-wnt1 transgenic mice. We found that loss of $R A R \alpha 1$ produced, in pubertal glands, a highly branched ductal epithelial tree phenotype, which was epithelial cell autonomous. Because retinoids are well known for regulation of embryonic stem cells [12,16-18], and, in one case, adult HSCs [19], and because adult stem cells are known to be involved in mammary gland morphogenesis [20-27], we hypothesized that loss of $R A R \alpha$ might affect the mammary stem cell compartment. Moreover, because wnt1 oncogenesis is believed to target mammary stem cells or bi-potent progenitors and might be responsible for progenitor amplification [20,28-30], we predicted that the $R A R \alpha 1 / \mathrm{KO}$ glands with the complex epithelial tree phenotype, will be more susceptible to wnt1-tumorigenesis.

We now show that epithelial cells derived from the highly branched ductal mammary tree of the $R A R \alpha 1 / \mathrm{KO}$ glands contain higher percentage of luminal progenitor cells, that they form larger primary mammospheres when cultured under adhesion-free and serum-free conditions, and that their MaSC-containing compartment is smaller than that of the wild type (wt)-glands. We further show that activation of RAR $\alpha$ by a specific agonist inhibits primary wt-mammospheres growth. Our published work [31], showed that chronic treatment of MMTV-wnt1 mice with the same RAR $\alpha$ agonist inhibited mammary tumor formation and growth. In spite of all these inhibitory effects of activated RAR $\alpha$ we found a significant increase in tumor-free survival when mice null for $R A R \alpha 1$ were crossed with MMTV-wnt1 transgenic mice. We propose that in vitamin-A replete conditions, $R A R \alpha$ guards normal morphogenesis and influences wnt-induced tumorigenesis at least in part by maintaining a proper hierarchy of the mammary epithelial compartments.

\section{Materials and methods}

Animals

RAR $\alpha 1$-/- mice (129/Bl-6 background) were generated in Pierre Chambon's laboratory (IGBMC, Strasbourg, France), and MMTV-wnt1 mice (FVB, SJL, and Bl/6 mixed background, with FVB prevalence) were generously provided by Dr. Yi Li (Baylor College of Medicine,
Houston, TX, USA). The RAR $\alpha 1-/+$ female mice were crossed with hemizygous male MMTV-wnt1 mice followed by intercrossing of $\mathrm{F} 1$ progeny that was $R A R \alpha 1+/-$ and MMTV-wnt1 transgenic, until sufficient mice for study were obtained. Genotyping was carried out by PCR. To obtain $R A R \alpha 1-/-$ in FVB background $R A R \alpha 1+/$ - females were backcrossed eight times with FVB males. All animal experiments were conducted in accordance with the IACUC approved protocols following the Mount Sinai Guidelines.

\section{Whole mounts of mammary glands and quantification of side branching and mature terminal end buds}

Mammary glands were excised, fixed in Carnoy's fixative and stained in carmine alum solution as described in reference 32 [32]. The neonatal glands were photographed and JPG files analyzed using the ImageJ software. The entire mammary tree in the abdominal number four gland/group was circumscribed and the Integrated Density of the area was measured in pixels. The branch points were counted in the three largest ducts in seven pairs (a total of 14 glands) of number four glands from the nipple to the periphery of the fat pad and the mature terminal end buds along the periphery of the fat pad.

\section{Mammary gland transplantation}

Fragments (approximately $2 \mathrm{~mm}^{3}$, approximately 30,000 cells) of mammary glands of 8 - to 10 -week-old virgin mice (wt or $R A R \alpha 1 / \mathrm{KO}$ ) taken from the area between the nipple and the LN, were transplanted into epithelium pre-cleared glands of three-week-old wild type or $R A R \alpha 1 / \mathrm{KO}$ animals, as previously described [33]. The recipient glands were excised and processed as for whole mounts eight weeks after transplantation. Seven mice were sham transplanted.

\section{Quantification of stem/progenitors using FACS analysis}

Mammary gland numbers four and five of seven- to eightweek-old female mice were isolated, minced and digested in trypsin/collagenase. The epithelium was freed of adipocytes by centrifugation and red blood cells were lysed. The remaining cells were treated exactly as described [34]. For the characterization of MaSC-containing and luminal progenitor containing compartments, cells $\left(1 \times 10^{6}\right.$ cells/ sample in duplicate) were incubated with PE or APCconjugated anti-CD24 Ab (BD Pharmingen, San Jose, $\mathrm{CA}, \mathrm{USA}$ ), APC-conjugated anti-CD29 Ab (Invitrogen, Camarillo, CA, USA) and FITC-conjugated anti-CD61 Ab (eBioscience, San Diego, CA, USA). In all other flow cytometry experiments, ALDH activity was determined by the Aldefluor assay according to manufacturer's directions (Aldegen, Durham, NC, USA), followed by CD24 antibody (1:100, biotin conjugated, BD Pharmingen, secondary 
antibody 1:1000 streptavidin-Alexa 633 and incubation on ice for 30 minutes). A pool of cells from approximately 10 mice was routinely used for each experiment. FACS analysis was carried out using a FACScanto flow cytometer, DIVA software program for acquisition (BD Biosciences) and Flowjo (Treestar, Inc. Ashland, OR, USA) software for analysis.

\section{Growth of mammospheres}

Mammary epithelial cells prepared as described for FACS analysis were further dissociated by pipetting and filtering through a $40 \mu$ pore cell strainer. (Occasional small clumps of up to six cells remained). Between 2.5 to $5.0 \times 10^{4}$ cells were plated in ultra low adhesion 24-well plates (Corning, Corning, NY, USA) and incubated in serum-free F12/DMEM 50:50 medium (Cellgro, Mediatech, Inc., Manassas, VA, USA) supplemented with $20 \mathrm{ng} / \mathrm{ml} \mathrm{EGF}$ and 1:50 B27 Supplement (Invitrogen, Carlsbad, CA, USA). When treatment was indicated, the agonist and antagonists were added after 8 to 10 days of incubation at $10 \mathrm{nM}$ for Am580, $200 \mathrm{nM}$ for at RA, and 10-fold excess of Ro41-5253 RAR $\alpha$ antagonist, $100 \mathrm{nM}$ or $2 \mu \mathrm{M}$, respectively, and the mammospheres were incubated for approximately eight days with partial medium and drug replenishment every two days. Mammospheres from four to eight wells were combined, allowed to settle at $1 \mathrm{~g}$, dissociated with EDTA, Joklik's medium and a brief trypsin treatment, followed by Soybean trypsin inhibitor (Sigma, St. Louis, MO, USA) and cells from at least duplicate culture pools were counted either in hemacytometer or in $5 \mu \mathrm{l}$ droplets in duplicates. For second passage the dissociated cells were re-plated as above. In some experiments mammospheres were counted before dissociation.

\section{Expression of RAR by Q-PCR}

RNA was isolated from primary mammary epithelial cells using RNeasy kits (Qiagen, Valencia, CA, USA), according to the manufacturer's protocol. cDNA was synthesized from $2 \mu \mathrm{g}$ of RNA using RevertAid M-MuLV reverse transcriptase (Fermetas, Geln Burnie, MA, USA). Q-PCR was performed using the $2 \times$ SYBR Green master mix (Applied Biosystems, Carlsbad, CA, USA) with $300 \mathrm{nM}$ primers and 40 ng of cDNA. To determine the fold change in expression, the $C_{t}$ value was averaged from triplicates for each sample. To normalize the RARs expression, triplicates for $\mathrm{Ct}$ from the $R A R$ gene was averaged and divided by the average of the triplicate from the GAPDH gene. The PCR primers used were: $R A R \beta 2$ for: 3' CTT CCT CCT GCA TGC TGC AG 5', RAR 22 rev: 5' GG CAC TGA CGC CAT AGT GGT A 3'; RAR $\gamma 1$ for: 3;' TGG GGC CTG GAT CTG GCT A 5', RAR $\gamma 1$ rev: 5' AT CTC CTC CGA GCT GGT GCT 3'; RAR 2 for: 3' CGG ACT TGA GTC
TTT TGC CTG 5', RAR 2 rev: 5' GCT CTG TGT CTC CAC CGA TT 3'.

\section{Activation of wnt-pathway}

Cells from three individual MMTV-wnt1 tumors in the first or second passage in culture, were transfected with the $\beta$-catenin reporter TOP-FLASH plasmid and renilla luciferase plasmid (pRL-SV4) in triplicates using Lipofectamine LTX (Invitrogen). After approximately $20 \mathrm{hr}$ incubation, $4 \mu \mathrm{M}$ Ro41-5253 was added and 24 hr later the cells were lysed in $1 \times$ passive lysis buffer (DualLuciferase Reporter Assay System, Promega, Madison, WI, USA) and assayed for luciferase using the DualLuciferase reporter (DLR) Assay System (Promega).

\section{Identification of bi-potential cells in mammospheres}

Eight-day-old mammospheres were dissociated and plated at one cell/ $20 \mu \mathrm{l}$ of medium in 96 -well plates (400 wells). Wells with single cells (118 total) were marked and incubated in medium with serum with weekly medium changes for a month. Of these only 21 produced colonies; these were stained with anti-CK14 (Neomarkers, Fremont, CA, USA; 1:200, secondary anti-rabbit-Alexa 488, 1:500, Molecular Probes, Invitrogen) and anti-CK18 (Sigma, St. Louis, MO, USA; 1:400, anti-mouse-Alexa 568, 1:500, Molecular Probes) and DAPI, examined under fluorescent Nikon Eclipse E600 microscope and photographed with SPOT-RTTM camera, Spot Diagnostic Instruments (Sterling Height, MI, USA) (× 200).

\section{Kaplan-Meier disease-free survival curves}

MMTV-wnt1 and MMTV-wnt1-RAR $\alpha 1 / \mathrm{KO}$ mice were palpated weekly (all five-gland pairs were examined) by the same investigator. The appearance of the first palpable tumor was recorded. Mice were euthanized when tumors reached a size of approximately $1 \mathrm{~cm}^{3}$ and parts of the tumors were taken for histological analysis (formalin fixation), RNA analysis (RNAlater), and in some cases for preparation of primary cultures and/or transplantation. Histological analysis of the tumors was performed by the Mutant Mouse Pathology Laboratory at UC Davis and by Mount Sinai's Center for Comparative Medicine and Surgery. Statistical analysis was done using the Log-rank test for the Kaplan-Meier survival studies and by two-way ANOVA test for the tumor growth studies. Significant differences were considered at $P<0.05$. Specific methods are indicated in figure legends.

\section{Tumor transplantation}

For transplantation, fragments (approximately $1 \mathrm{~mm}^{3}$ ) of MMTV-wnt1 and MMTV-wnt1-RAR $1 / \mathrm{KO}$ tumors were transplanted with an implant needle (Fisher, 
Pittsburgh, PA, USA) into opposite sides between gland numbers three and four of anesthetized eight-week old FVB mice (four mice per experiment, repeated three times). Each transplant consisted of three randomly chosen tumor fragments from a mince. Tumor diameter was measured twice a week with a caliper. For determination of tumor latency and tumor take, primary wnt or $R A R \alpha 1 / \mathrm{KO}-w n t$ tumors were dissociated, the single cells counted and $10^{5}$ or $10^{4}$ viable cells were injected into FVB mice as above.

\section{Results}

We studied a single $R A R$ isoform knockout (KO) mice $(R A R \alpha 1 / \mathrm{KO})$ because compound $R A R$ mutants are embryonic or perinatal lethal whereas, with some exceptions, single isoform mutants are viable, fertile, and have a normal life span. We focused in this work on the role of the RAR $\alpha 1$ isoform which, directly, or through $R A R \beta$ expression, has been implicated in growth suppression of normal and cancerous breast cells in vitro $[2,6,7]$.

\section{RAR $\alpha$ controls mammary development before and during puberty}

We analyzed $R A R \alpha 1 / \mathrm{KO}$, and wild type (wt) mammary whole mounts from female mice of 129/C57Bl-6 genetic backgrounds in the first week after birth, during puberty, pregnancy, lactation, involution and postinvolution and mice in FVB background after birth and during puberty. (Two genetic backgrounds were used because mammary morphology has been shown to be genotype-dependent $[35,36])$. A major effect of $R A R \alpha 1 / \mathrm{KO}$ was found in the newborn and the pubertal glands (Figure 1A-E); other developmental phases were ostensibly normal, (Results not shown). In the RAR $\alpha 1 / \mathrm{KO}$ neonatal glands of 129/C57Bl-6 and FVB mice the epithelial ductal tree extended approximately two-fold further into the fat pad (Figure 1A). In pubertal wt-glands, (six to eight weeks old) at diestrus the ductal tree filled most of the fat pad but several terminal end-buds (sites of active proliferation) still remained (Figure 1B, E, left panels). (The phenotype was also present in other parts of the estrus cycle, results not shown). There was a two-fold increase in branch points and a five-fold increase in the number of mature end-buds in the $R A R \alpha 1 / \mathrm{KO}$ fad pad (Figure $1 C, D)$. This effect was specific to $R A R \alpha 1 / \mathrm{KO}$ as $R A R b 2 / \mathrm{KO}$ mice did not show a change in branching morphogenesis (results not shown) and $R A R \alpha 1 / \mathrm{KO}$ produced similar branching phenotype in two different genetic backgrounds (Figure 1B, E, whole mount and histological sections). Thus, loss of a single RAR isoform has a major effect on the expansion of the neonatal ductal tree and branching morphogenesis in pubertal mice.

\section{The increased ductal branching is predominantly epithelial-cell autonomous}

To exclude systemic effects of $R A R \alpha 1 / \mathrm{KO}$ on mammary morphogenesis, epithelium-containing mammary fragments, estimated to contain approximately 30,000 epithelial cells, were transplanted from adult FVB-wt or $R A R \alpha 1 / \mathrm{KO}$ donor mice into epithelium-divested, abdominal number four glands of FVB-wt and RAR $\alpha 1 /$ $\mathrm{KO}$, three-week old recipient mice such that the experiment was always internally controlled. The transplanted number four glands and the number three glands from the recipient mice, used as internal controls, were excised eight weeks later, and their phenotype examined in whole mounts. We found (Figure 2) that donor tissue from wt and $R A R \alpha 1 / \mathrm{KO}$ mice was able to repopulate the recipient glands; the highly branched ductal tree of the RAR $\alpha 1 / \mathrm{KO}$ donor was fully reconstituted in a wtFVB recipient, indicating that the phenotype was epithelial cell autonomous. The "penetrance" of the KOphenotype was slightly greater when both the donor and the recipient mouse were of the KO-type, (75\% KOphenotype in wt-recipients and $86 \%$ in $R A R \alpha 1 / \mathrm{KO}$ recipients, Table 1 ), suggesting possibly a minor systemic effect. The majority ( $86 \%$ and $87 \%$ ) of wt-FVB transplants had the expected wt-phenotype in the FVB-wt and $R A R \alpha 1 /$ KO recipients, (Table 1 ).

\section{Primary RAR $\alpha 1 /$ KO mammary gland mammospheres contain more cells}

We wondered whether the increased branching and, presumably, the increased epithelial content of the $R A R \alpha 1 / \mathrm{KO}$ gland is a result of a larger stem/progenitor cell pool. As a first test of this idea we prepared single cell suspensions of partially purified mammary epithelial cells from glands of seven- to eight-week-old wt or $R A R \alpha 1 / \mathrm{KO}$ mice, seeded them under mammospheres conditions, dissociated the mammospheres after eight days of attachment-free growth and counted the individual cells [37]. As shown in Figure 3A, in four independent experiments, wells seeded with $R A R \alpha 1 / \mathrm{KO}$ derived epithelium produced mammospheres that, upon dissociation, had approximately two-fold more cells $(P=0.01)$ than those obtained from wt-epithelium. The difference in the number of mammospheres, which were difficult to count, was slightly and not significantly lower in the $R A R \alpha 1 / \mathrm{KO}$ cultures. We were unable to efficiently passage any mammospheres beyond Passage 3.

Although, mammospheres are considered to be useful culture correlates to stem cells, it appears that only a small percent of mammosphere cells have repopulating in vivo potential, and their derivation and composition, especially in the mouse mammary, is still debated $[25,38]$. We characterized the primary mammospheres 

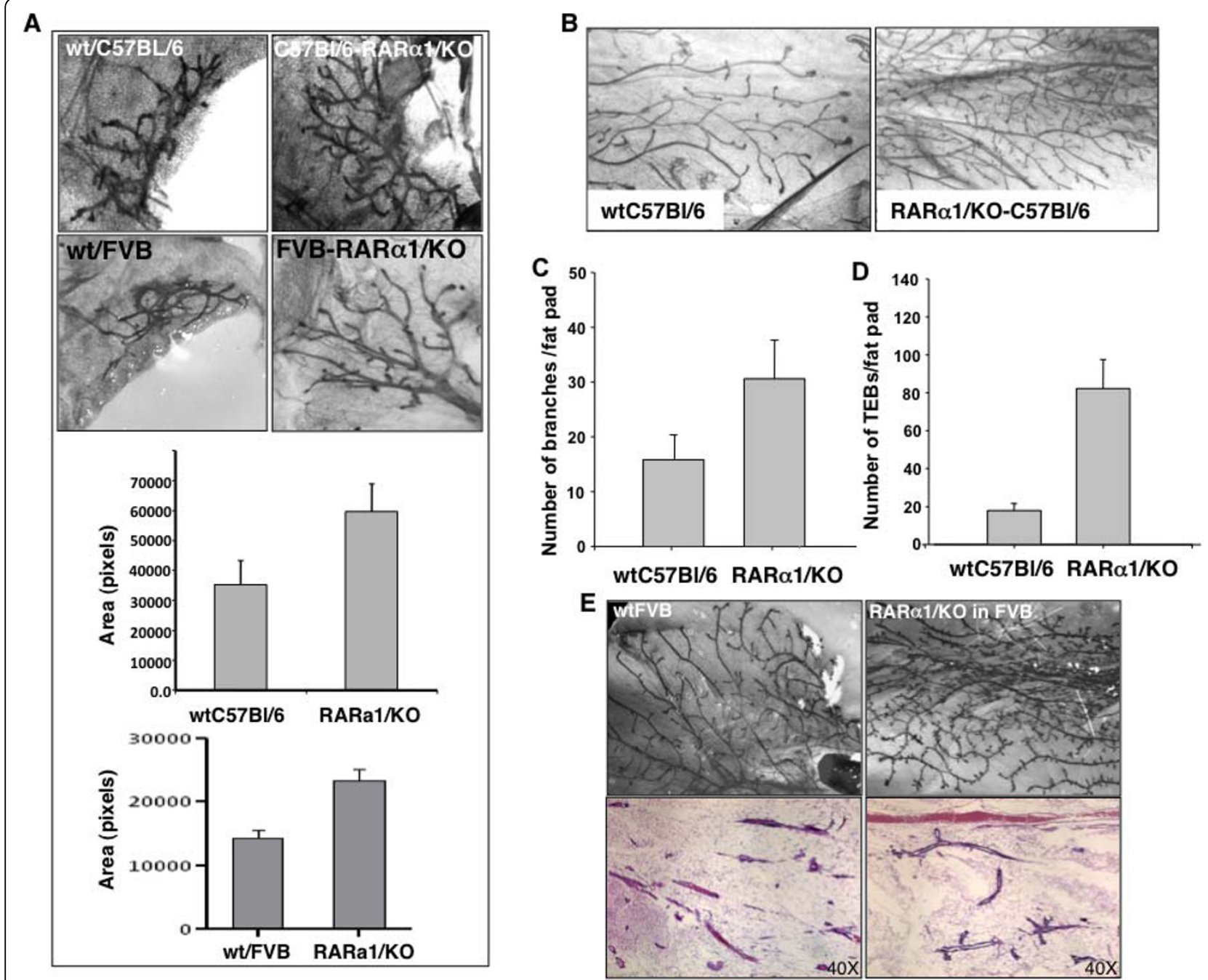

Figure 1 The effect of $R A R \alpha 1 / K O$ on neonatal and pubertal gland development. (a) Effect on the size of the neonatal glands. Number 4 glands were dissected from five to six days old wt and RAR $1 / \mathrm{KO}$ C57BI/6 or FVB, four mice per group, and whole mounts were prepared as described in Materials and methods. The area taken up by the mammary tree was analyzed using the Image J software. Bars are mean and SD of four glands per group. (b-e) Effect on pubertal mammary tree branching morphogenesis and terminal end buds. Number 4 mammary glands from seven to eight weeks old wt or RAR $\alpha 1 / K O$ C57BI/6 (b-d) and FVB pubertal mice (e) were dissected and processed for whole mounts and paraffin sections. Branching points were counted along the entire length of the three longest ducts. Bars show mean and SD of seven pairs (14 total) of number 4 glands per group $(P=0.0001, t$-test). The same glands were used to count the peripheral terminal end buds (TEBs) $(P=$ $0.00001, t$-test).

for the presence of bi-potential progenitors [39]. This was done by inoculating single cells obtained from primary mammospheres into small wells, and when colonies were established, staining them for cytokeratin CK14 (myoepithelial cells) and CK18 (luminal cells). Of a total of 118 wells with single cells which started dividing, only 21 (18.6\%) formed, after a month of incubation, large enough colonies to be stained with antibodies to CK14 and CK18. We found (Figure 3B) that only $30 \%$ of the colonies produced by single cells were bipotential, with individual cells within the colony expressing either CK18 or CK14; 55\% of the colonies expressed exclusively CK18, (luminal), and 15\% exclusively CK14 (myoepithelial) markers. Thus more than $80 \%$ of cells in mammospheres are unable to produce colonies in adherent culture, and of those cells that make colonies, only approximately $30 \%$ are bi-potential.

\section{RAR-activation is involved in growth of primary mammospheres}

To better link the increase in cell number in the RAR $\alpha 1 / \mathrm{KO}$-derived mammospheres with the RAR pathway, wt-mammary epithelial cells were allowed to form mammospheres and were either left untreated or were 

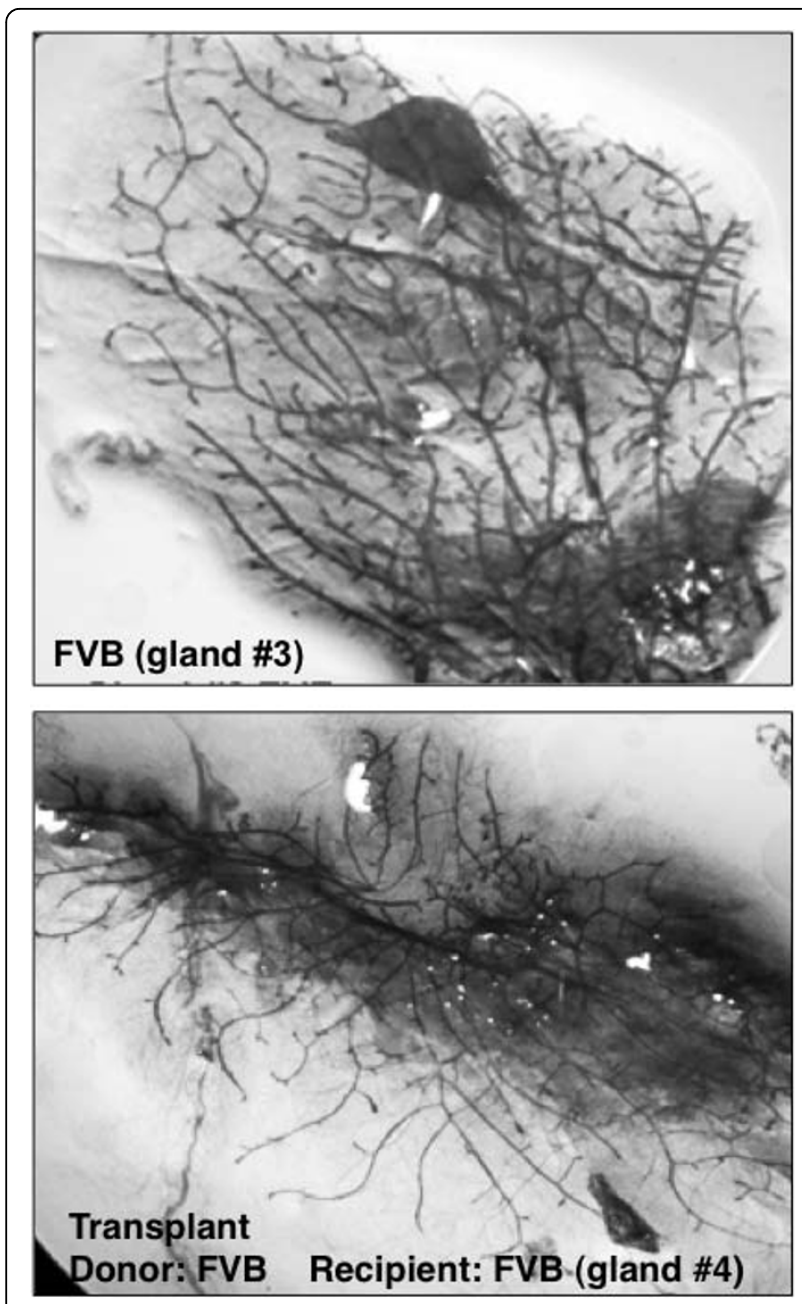
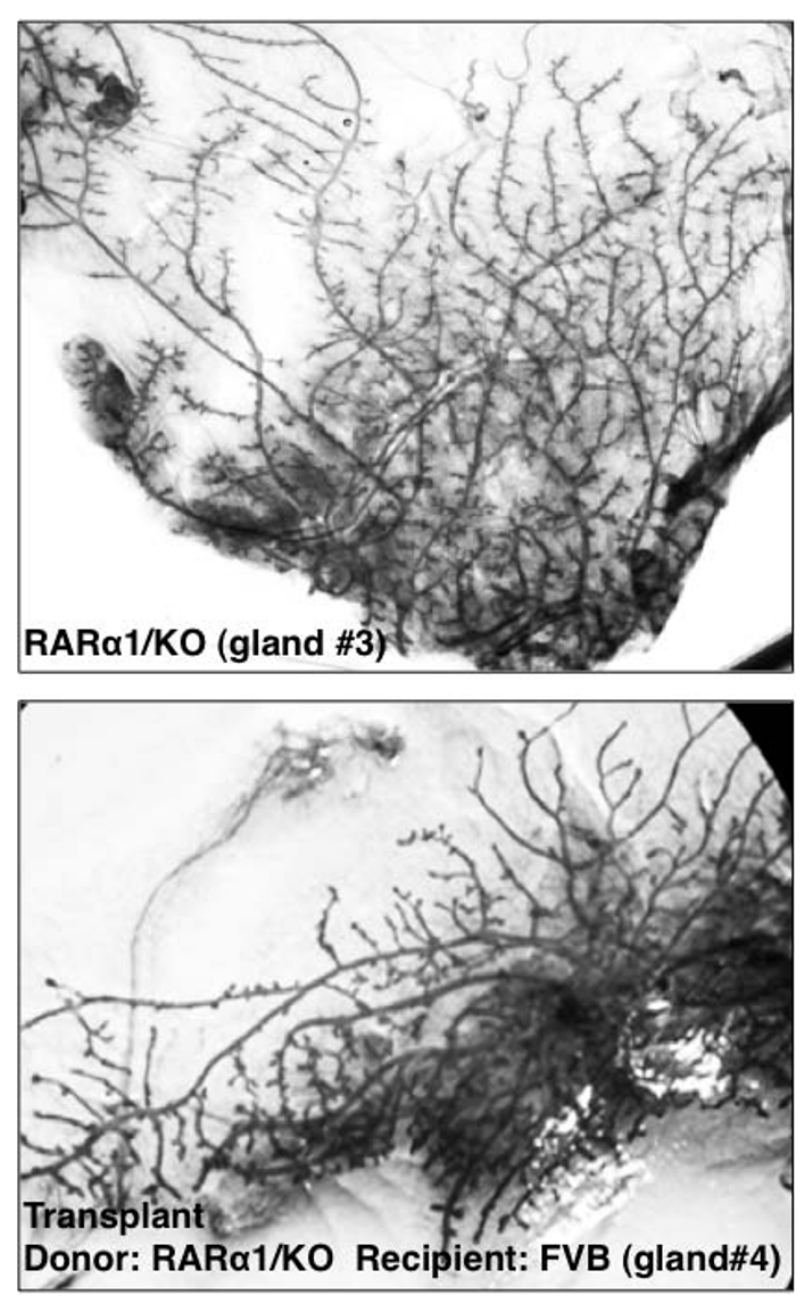

Figure 2 Mammary gland transplantation. Fragments of epithelium containing mammary glands of eight to ten weeks old virgin mice (wt or $R A R \alpha 1 / \mathrm{KO}$ ) were transplanted into number 4 glands pre-cleared of epithelium of three weeks old wild type or RAR $\alpha 1 / \mathrm{KO}$ animals (see Materials and methods). At week 11 (eight weeks after transplantation) the transplant-recipient glands and intact glands number 3 from the same mouse, as control, were processed for whole mounts. $>90 \%$ of wt-FVB transplants repopulated the recipient gland while $<50 \%$ of the FVB-RAR $1 /$ KO did (see Table 1).

treated for eight days with $10 \mathrm{nM}$ Am580, (a RAR $\alpha$ agonist) or with Am580 combined with a 10-fold excess of Ro41-5253, a RAR $\alpha$ antagonist, at which time the mammospheres were enzymatically dissociated and single cells counted. We found that activation of RAR $\alpha$ by Am580 reduced mammosphere growth by $50 \%$, while RAR $\alpha$-antagonist in presence of Am580, completely reversed this inhibition (Figure $3 \mathrm{C}$ ), mimicking to some degree the loss of $R A R \alpha 1$. We also found that mammospheres treated with $100 \mathrm{nM}$ atRA, an agonist for all three RARs, in presence of the specific RAR $\alpha$ antagonist, boosted the cell number in mammospheres even above that of untreated controls (Figure 3C). Comparison of RAR expression by Q-PCR in RNAs extracted from wt and $R A R \alpha 1 / \mathrm{KO}$ epithelial cells isolated directly from the mammary glands, showed that all three $R A R$ isotypes were present, but while there was no difference in $R A R \alpha 1 / 2$ and $R A R \beta 2$ expression (results not shown),

Table 1 Epithelial-autonomous phenotype of RAR $\alpha 1$-null phenotype

\begin{tabular}{|c|c|c|c|c|}
\hline Categories & RAR $\alpha 1$-null to FVB & $R A R \alpha$-null to $R A R \alpha$-null & FVB to FVB & FVB to $R A R \alpha$-null \\
\hline Total number transplanted & 17 & 18 & 30 & 17 \\
\hline Successful gland repopulation (\%) & 47.0 & 39.0 & 93.3 & 94.1 \\
\hline Expected phenotype (\%) & $75.0^{1}$ & $86.0^{1}$ & $86.0^{2}$ & $87.0^{2}$ \\
\hline
\end{tabular}

\footnotetext{
${ }^{1}$ Increased ductal tree branching, more total and mature TEBs, ${ }^{2}$ Normal branching phenotype.
} 


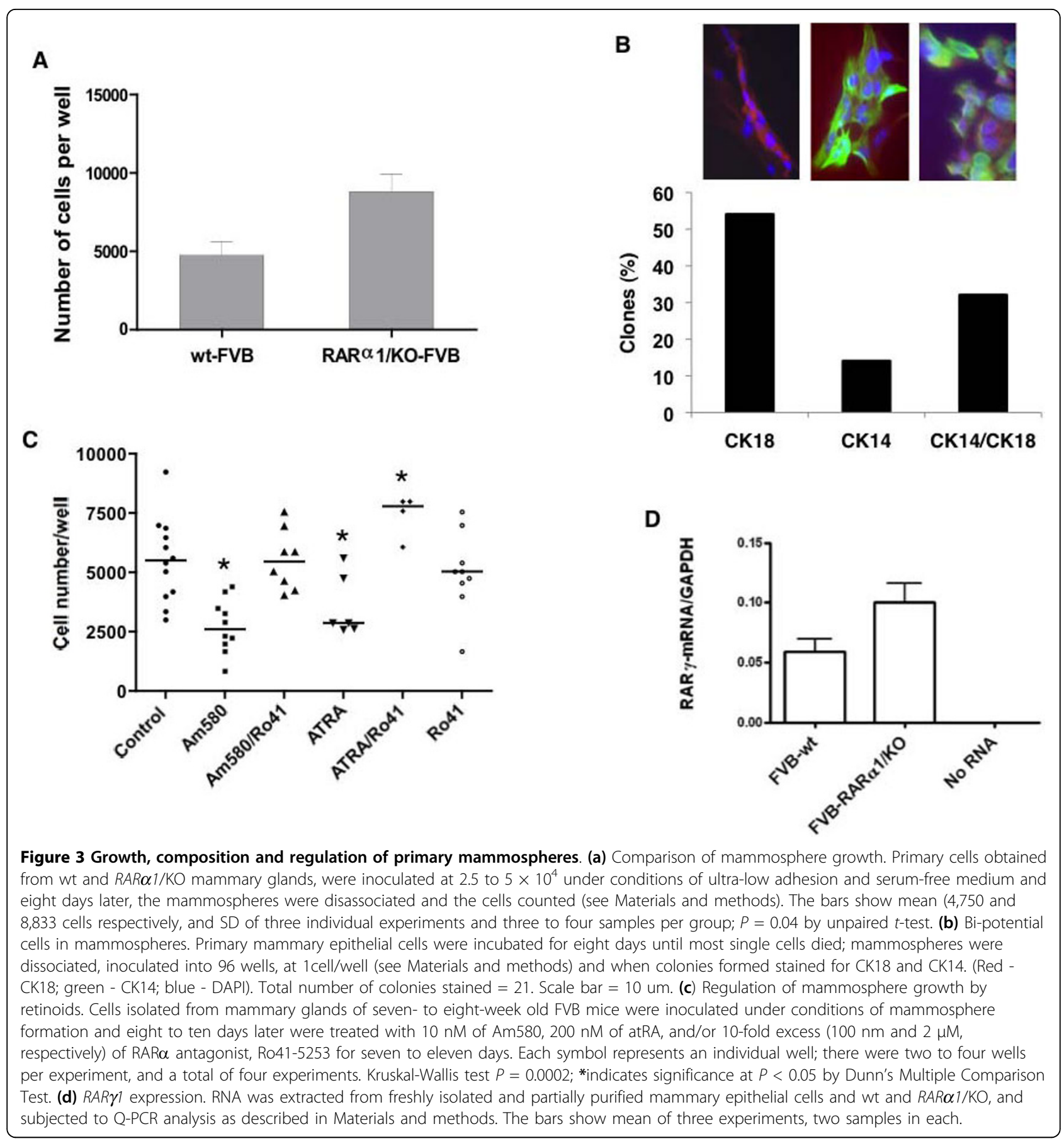

in three independent tests, the $R A R \gamma 1$ expression was increased by almost two-fold in the $R A R \alpha 1 / \mathrm{KO}$ cells (Figure 3D). Our previous work [31], showing a proproliferative role of $\mathrm{RAR} \gamma$ suggests that, in addition to blockade of the RAR $\alpha$, the increased RAR $\gamma 1$ might have contributed to the cell increase in mammospheres treated with atRA and Ro41-5253 (Figure 3C). Whether this effect was mediated through a specific effect on the progenitors remains to be determined.
RAR $\alpha 1$ loss affects mammary epithelial hierarchy and mammary repopulating efficiency

We first tested the effect of $R A R \alpha 1 / \mathrm{KO}$ on the stem/ progenitor compartment of the mammary epithelium. This was done by determining the percent of cells expressing low levels of CD24 antigen (CD24 ${ }^{\text {low }}$ ) and showing high ALDH activity (ALDH ${ }^{\text {high }}$ ) in cell suspensions of partially purified mammary epithelial cells from glands of seven- to eight-week-old wt or $R A R \alpha 1 /$ 
KO mice. These markers were shown to define a population encompassing the mammary repopulating cells but also progenitors $[24,34,40]$. A representative FACS analysis (Figure 4A) shows that the $R A R \alpha 1 / \mathrm{KO}$ epithelium contains more CD24 ${ }^{\text {low }}$ ALDH ${ }^{\text {high }}$ cells than wt-epithelium. In a total of seven experiments (Figure 4B), we found a statistically significant, $(P=$ 0.01 ), median 1.7 -fold increase in these cells in $R A R \alpha 1 / \mathrm{KO}$ glands. To test which specific subpopulations were affected by the loss of RAR $\alpha 1$, we used an additional surface marker, (CD29). Populations of
CD24 ${ }^{\text {low }}$ cells with high expression level of CD29 (and/ or CD49f) represent the MaSC-containing compartment, while CD24 $4^{\text {high }} / \mathrm{CD} 29^{\text {low }}$ are considered to be luminal progenitors [25]. As shown in Figure 4C, the $R A R \alpha 1 / \mathrm{KO}$ mammary epithelium contained greater percentage of progenitors (CD2 $4^{\text {high }} / \mathrm{CD} 29^{\text {low })}$ but fewer MaSCs $\left(\mathrm{CD} 24^{\text {low }} / \mathrm{CD} 29^{\text {high }}\right)$ than wt glands. Importantly, the ratio of progenitors/MasSCs in the $R A R \alpha 1 / \mathrm{KO}$ epithelium was 1.9 , while in the wt glands it was only 0.8 . Both progenitors and MaSC-compartment were positive for CD61 (results not shown).

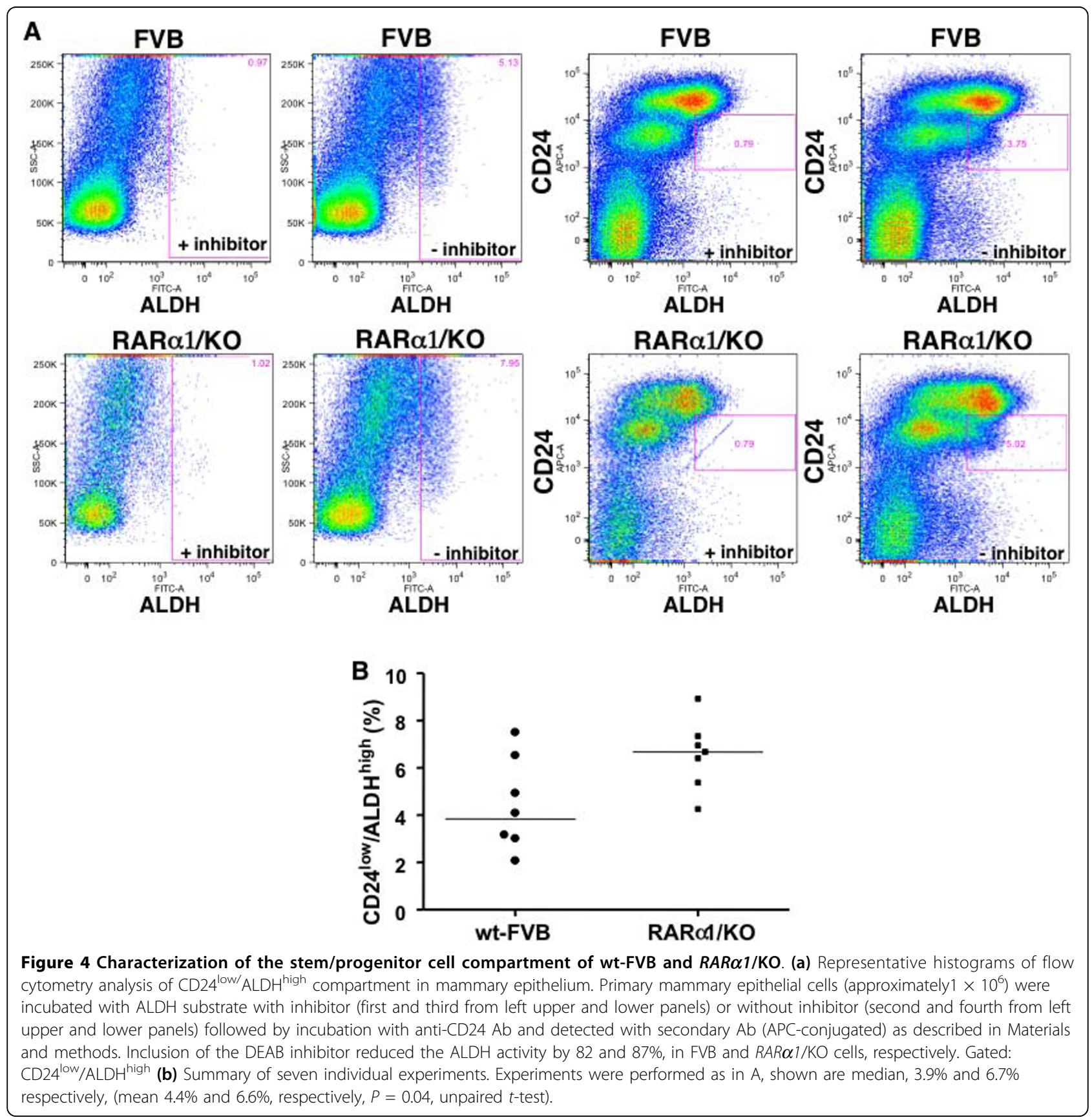


The increase in the MaSC-containing compartment of wt glands suggest that these epithelium might be more effective in repopulating epithelium-divested mammary glands. To test this we transplanted mammary fragments containing approximately 30,000 cells which, according to published reports [25] should contain 1 to 10 stem cells). As shown in Table 1, while $>90 \%$ of the wt-donors produced successful transplants, only $47 \%$ of $R A R \alpha 1 / \mathrm{KO}$ mammary fragments were successful when transplanted into wt-mice. (The rate went down to $39 \%$ when the recipients were $R A R \alpha 1 / \mathrm{KO}$ mice). Thus, similar size fragments of $R A R \alpha 1 / \mathrm{KO}$ glands contain proportionally fewer stem cells, or contain stem cells with impaired activity. Although, preliminary, this finding is in agreement with the increased MaSC-compartment of the wt-mammary (Figure 5) and suggests that loss of $R A R \alpha 1 / \mathrm{KO}$ may alter the normal hierarchy of mammary epithelium.

Loss of RAR $\alpha 1$ delays mammary tumor development in MMTV-wnt 1 mice, slows the growth and increase latency of transplanted tumors

The target cell of wnt1-oncogenesis in mammary gland has been identified as the stem cell, the progenitor or both. It has been also shown that wnt1 can expand and change the stem cell compartment $[20,28,41,42]$. We confirmed, using CD2 $4^{\text {low }} / \mathrm{ALDH}^{\text {high }}$ as markers, that epithelial cells from MMTV-wnt1-glands had a much higher proportion of these cells (mean $8.2 \%$ Figure 6A) than wt-glands and their content was further increased (mean $11.2 \%$, Figure $6 \mathrm{~A}$ and $6 \mathrm{~B}$ ) in the bi-genic $(R A R \alpha 1 / \mathrm{KO} \times \mathrm{MMTV}$-wnt 1$)$ mammary glands. We noted that unlike the wt-cells, which had distinct high and low CD24 populations, the wnt1 expressing cells had a more homogenous and lower expression of CD24, precluding their further sub-division based on this marker. This change has been seen previously $[20,28,41,42]$. Since both stem cells and progenitors are considered to be wnt1-targets, the changes we observed in these compartments made it difficult to predict what effect the loss of RAR 1 will have on mammary tumorigenesis. To test this, mammary glands of 40-MMTV-wnt1 and 42MMTV-wnt1-RAR $\alpha 1 / \mathrm{KO}$ young female mice were palpated weekly for 40 weeks, and the appearance of palpable tumors was recorded. Mice were sacrificed and the tumors collected when they reached the size of approximately $1 \mathrm{~cm}^{3}$. Kaplan-Meier analysis showed that the overall tumor-free survival was significantly $(P=0.0002)$ longer in the bi-genic mice and that, compared to MMTV-wnt1 mice, approximately three times as many

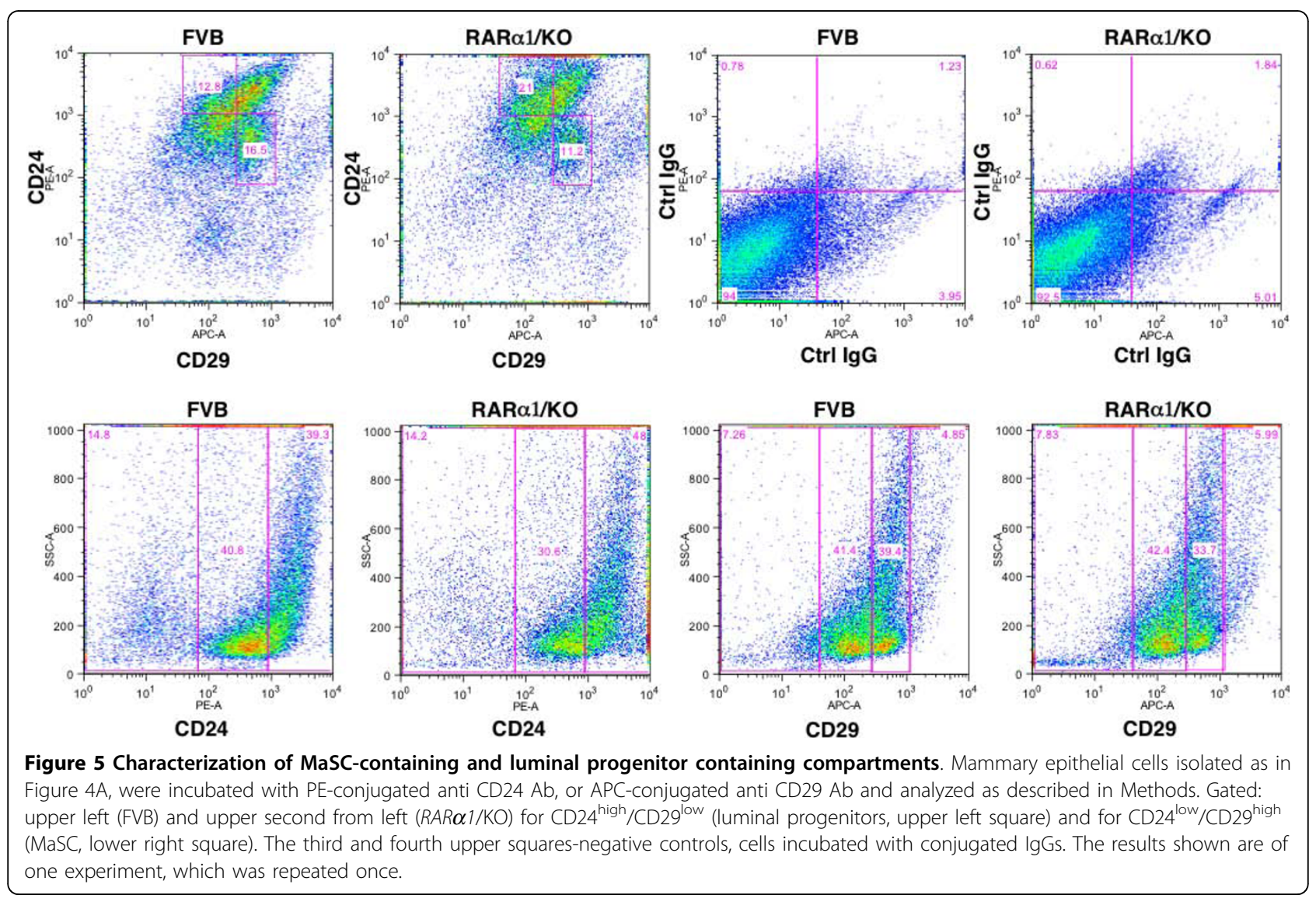




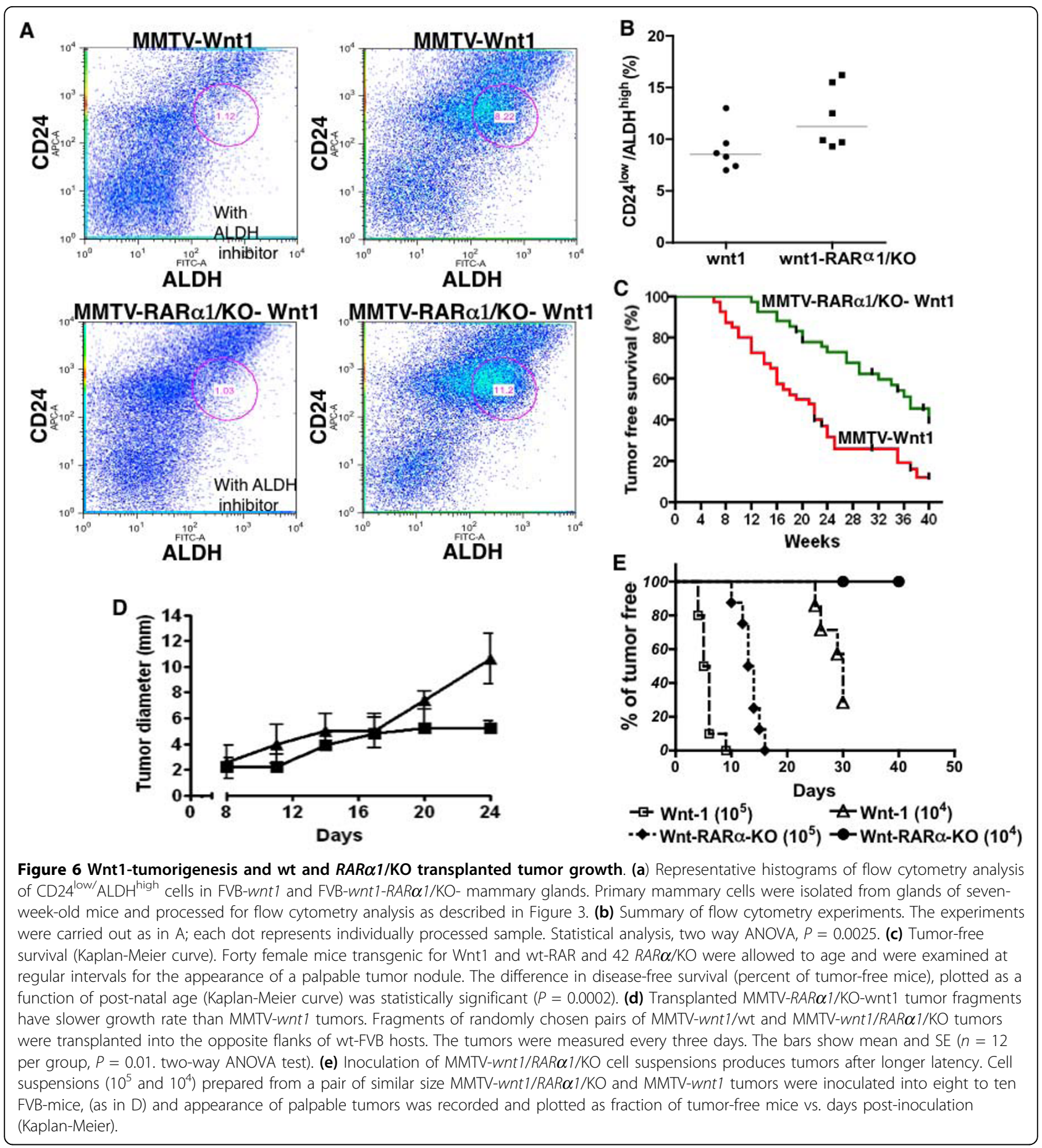

MMTV-wnt1-RAR $\alpha 1 / \mathrm{KO}$ mice were tumor-free at the end of the $40^{\text {th }}$ week follow up (Figure 6C). H\&E stained sections of the wnt1 and bi-genic tumors had similarly typical wnt-histology (results not shown). This result suggests that the reduction in the MaSCs containing sub-population, by reducing the target population, might be one mechanism through which $R A R \alpha 1$ loss slows down wnt1-oncogenesis.
Because these experiments were done in mice with germ line $K O$ of RAR $\alpha 1$, to link the effect to the tumor itself, we transplanted fragments of wht1-RAR $\alpha 1 / \mathrm{KO}$ and wnt-tumor on the contralateral sides of four wtmice between the third and the fourth mammary gland. The mice were palpated weekly and once tumors were detected, their diameters were measured every three days. Figure 6D shows that between Day 8 and 17 the 
wt-wnt1-derived tumors showed a small growth advantage over the wnt1-RAR $\alpha 1 / \mathrm{KO}$ tumors, but in the next seven days they grew exponentially, reaching the weight of $500 \mathrm{mg}$, (calculated from the measurements of tumor diameter), while the growth of wnt1-RAR $\alpha 1 / \mathrm{KO}$ tumor leveled off at about $60 \mathrm{mg}$. Thus, even in a $R A R$-intact systemic environment, the growth of transplanted tumor cells lacking $R A R \alpha 1$ was delayed.

To measure tumor latency, $10^{5}$ and $10^{4}$ single cell suspensions obtained from wnt1 and wnt1-RAR $\alpha 1 / \mathrm{KO}$ tumors were injected as above and the time of palpable tumor appearance was recorded. Figure 6E (Kaplan Meier plot) shows that, at both cell concentrations, cells derived from the wnt1-RAR $\alpha 1 / \mathrm{KO}$ tumors had much longer latency.

\section{Discussion}

Our results provide evidence that at physiological levels of vitamin A, a single $R A R$ isoform, $R A R \alpha 1$ participates in the control of normal branching morphogenesis of the pubertal mammary epithelial tree. This is evidenced by the excessive side budding and secondary branching observed in mice of two genetic backgrounds when $R A R \alpha 1$ is knocked out (Figure 1). Although, control of mammary morphogenesis is complex and can be driven by both systemic [43-45] and local [46-48] effects, our mammary transplantation experiments results (Figure 2 and Table 1) indicate that in this capacity, $R A R \alpha 1$ functions in a predominantly epithelial-cell autonomous fashion. In addition to the effects in the pubertal gland, we found that loss of $R A R \alpha 1$ causes doubling of the rudimentary mammary tree in the neonatal gland (Figure1), suggesting a possible role for this receptor in embryonic mammary development. A similar branching phenotype has been described in transgenic mice overexpressing a DN-RAR mutant, which blocks all retinoid signaling [49], but, to the best of our knowledge, ours is the first described link between a single $R A R$ isoform and mammary epithelial growth and morphogenesis in vitamin A replete animals.

Based on the increased epithelial cellularity of the KO-glands and published data implicating $R A R \alpha$ in anticancer activity, we expected that the $R A R \alpha 1 / \mathrm{KO}$ mice crossed with the MMTV-wnt1 mice will be more susceptible to wnt1-induced tumorigenesis. Moreover, activation of retinoid signaling has been shown to inhibit the wnt1 pathway in cell culture [50,51]. Indeed, treatment of cells derived from three individual wnt1-tumors and transfected with a reporter for wnt 1 pathway activation (TCF/ $\beta$-catenin activity), when treated with an RAR $\alpha$ antagonist, Ro415253 produced a significant $(P=0.01)$ two-fold increase in the reporter (luciferase) activity (results not shown). However, unexpectedly, we found that MMTV-wnt1-RAR $\alpha 1 / \mathrm{KO}$ mice had significantly longer tumor-free survival than MMTV-wnt1 wt-mice (Kaplan Meier analysis, Figure 6). Moreover, in three independent experiments fragments of $w n t 1-R A R \alpha 1 / \mathrm{KO}$ tumors grew much more slowly than fragments of wnt 1 tumors when implanted into contra lateral sides of the same mouse, and single cells suspensions obtained from wnt1-RAR $\alpha 1 / \mathrm{KO}$ tumors showed much longer latency.

How is it possible that active RAR $\alpha 1$ which prevents apparent epithelial hyperplasia and blocks wnt pathway activity, also allows a more efficient wnt1-induced oncogenesis? The oncogenic targets of wnt 1 are believed to be progenitor/stem cells $[28,29]$ and wnt signaling might have a role in mammary stem cells self-renewal [24]. The uncertainty regarding the precise target comes from the difficulty in comparing stem cell compartments in normal mammary and in wnt 1 induced tumors. The situation is further complicated by the findings [42] that in the pre-neoplastic stage constitutive wnt1 signaling perturbs the epithelial hierarchy, leading to the emergence of aberrant multipotential stem-like cells in the committed luminal cell fractions. How can then our result fit into this complex scheme? We showed that pre-malignant wnt1-RAR $\alpha 1 / \mathrm{KO}$-glands have the highest content of $\mathrm{ALDH}{ }^{\text {high }} / \mathrm{CD} 24^{\text {low }}$ cells and that pubertal $R A R \alpha 1 / \mathrm{KO}$ mammary gland (without wnt1-expression) contains 1.7 times more of these cells than wt-mammary (Figures 4 and 5). Cells isolated from $R A R \alpha 1 / \mathrm{KO}$ and mammospheres produced by the RAR $\alpha 1 / \mathrm{KO}$ cells form larger mammospheres (Figure 3 ), possibly because the progenitors might proliferate more rapidly. These progenitors were shown to be elevated during puberty, concomitant with an increased ductal branching and elongation, a phenotype that is enhanced in the RAR $\alpha 1 /$ KO mice [52]. At the same time, however, we found a reduction in MaSc-enriched compartment and a reduction in repopulation efficiency of $R A R \alpha 1 / \mathrm{KO}$ mammaryfragments (Figure 2 and Table 1). Although, we did not perform consecutive in vivo passages of the transplants, the diminished capacity of the $R A R \alpha 1 / \mathrm{KO}$ fragments to repopulate, suggests that they contain fewer stem cells or, at the least, they contain stem cells with diminished activity.

That RAR $\alpha 1$ keeps in check the proliferative capacity of the progenitors in the pubertal gland and, that its loss leads to the enlargement of the progenitor compartment, fits with the established anti-proliferative role of RAR and retinoids. For example, p $27^{\text {kip }}$, a protein that accumulates in response to RAR activation, can limit the self-renewal of some adult tissue progenitors [53]. It is also possible, that in addition to removing a block to proliferation, loss of $R A R \alpha 1 / \mathrm{KO}$ provides an indirect proliferative stimulus mediated through RAR $\gamma 1$. We showed that $R A R \alpha 1 / \mathrm{KO}$ epithelium has higher levels of $R A R \gamma 1$-mRNA (Figure 3D), and that this isoform has 
pro-proliferative activity in mammary cells [31]. Moreover, wt-mammospheres treated simultaneously with atRA and an RAR $\alpha$ antagonist, a combination that allows RAR $\gamma$ (and $\beta$ ) activation (Figure $3 C$ ), yielded the highest numbers of cells.

Overall, our current data suggest that the profound reduction in mammary repopulating activity combined with the predominance of progenitors over MaSCcontaining compartment in the $R A R \alpha 1 / \mathrm{KO}$, by reducing wnt1 target might contribute to the delay in wnt1tumor development. The mechanism for this is unknown, but it has been shown that PTEN loss in HSCs causes a transient expansion of the stem cell pool followed by its depletion $[54,55]$. We have shown that RAR activation inhibits PI3K activity, thus loss of RAR $\alpha 1$ might possibly cause a similar effect to that of PTEN deletion. In an elegant study Purton et al. [19] have shown that loss of $R A R \alpha 1$, but not RAR $\alpha$, results in reduced numbers of HSCs and increased numbers of more differentiated progenitor cells in the mutant mice. Although, in the mammary it is the RAR $\alpha$ that appears to be involved, different RAR isotypes are known to have tissue-specific roles $[17,56]$.

Because wnt1 pathway activation is involved in human breast cancer [57], and RAR $\alpha$ has a proven role in breast cancer, the mechanism connecting RAR $\alpha 1$ to control of wnt-tumorigenicity is worthy of further study. It remains to be determined whether a reduction in stem cell level in $R A R \alpha 1 / \mathrm{KO}$ mice translates into reduced cancer stem cell level, what is the mechanism responsible for this reduction and whether it is the cause of increased tumor-free survival and a delay in growth of transplantable tumors.

In summary, we showed that loss of $R A R \alpha 1$ leads to reduced mammary stem cell content and an increase in wnt1-tumor free survival in mice. Under physiological conditions RAR $\alpha 1$ signaling appears to control the content of mammary stem/progenitor cell compartments and affect the proper morphogenesis of neonatal and pubertal mammary gland.

\section{Conclusions}

The established anti-proliferative effect of retinoids on breast cancer in culture and in selective in vivo models did not translate, so far, into a successful anti-breast cancer therapy. Our results led us to conclude that retinoic acid receptor isotypes might have unique functions in normal development and in oncogenesis and that some of the functions can only be discerned in vivo under physiological vitamin-A replete conditions. For example, RAR $\alpha 1$ appears to control the normal neonatal and pubertal morphogenesis of the mammary gland, most likely by controlling the size of the mammary stem cells (MaSCs) and progenitor compartments. Importantly, efficient wnt1-induced oncogenesis appears to be dependent on properly maintained MaCS/progenitor hierarchy. The RAR $\gamma$ isotype most likely has an opposing function. These unexpected results, together with recent publications by us and others, reveal the complexities of the RAR-signaling networks and suggest that to be successful, anti-breast cancer therapy will have to consider these newly identified intricacies.

\section{Abbreviations}

ALDH: aldhyde dehydrogenase; CD24low: heat stable antigen low; CK14: cytokeratin 14; CK18, cytokeratin 18; CRBP-1: cellular retinol binding protein 1; FACS: fluorescent activated cell sorting; H\&E: hematoxilin and eosin; HSC: human stem cells; LN: Iymph node; MaSC: mammary stem cells; MMTV: mouse mammary tumor virus; Q-PCR: quantitative polymerase chain reaction; RA: retinoic acid; RAR: retinoic acid receptor; RAR 1 1: retinoic acid receptor isotype alpha isoform 1; Wnt1: wingless-related MMTV integration site 1.

\section{Acknowledgements}

We express our appreciation to Dr. Pierre Chambon (IGBMC, Strasbourg, France) for the gift of RAR $\alpha 1 / \mathrm{KO}$ mice, and to Dr.Yi Li (Baylor College of Medicine, Houston, TX, USA) for the MMTV-wnt1 mice. This work was supported by the NCl grant CA54273, the Samuel Waxman Cancer Research Foundation, and the Chemotherapy Foundation.

This work is dedicated to the memory of Dr. Rafael Mira y Lopez, mentor and colleague, taken from us too early.

\section{Authors' contributions}

EC assisted in collection and assembly of data, data analysis and editing of the manuscript. LO assisted in conception and design, collection and assembly of data, data analysis, and manuscript writing. SB assisted in collection and assembly of in vivo data. CM assisted in collection, assembly and analysis of morphogenesis data. EFF assisted in conception and design, collection and assembly of data, and data analysis. All authors read and approved the final manuscript.

\section{Competing interests}

The authors declare that they have no competing interests.

Received: 2 February 2010 Revised: 9 July 2010

Accepted: 5 October 2010 Published: 5 October 2010

\section{References}

1. Wolbach SB, Howe PR: Nutrition Classics. The Journal of Experimental Medicine 42: 753-77, 1925. Tissue changes following deprivation of fatsoluble A vitamin. S. Burt Wolbach and Percy R. Howe. Nutr Rev 1978, 36:16-19.

2. Fitzgerald $P$, Teng M, Chandraratna RA, Heyman RA, Allegretto EA: Retinoic acid receptor alpha expression correlates with retinoid-induced growth inhibition of human breast cancer cells regardless of estrogen receptor status. Cancer Res 1997, 57:2642-2650.

3. Toma S, Isnardi L, Raffo P, Dastoli G, De Francisci E, Riccardi L, Palumbo R, Bollag W: Effects of all-trans-retinoic acid and 13-cis-retinoic acid on breast-cancer cell lines: growth inhibition and apoptosis induction. Int J Cancer 1997, 70:619-627.

4. Fontana JA, Hobbs PD, Dawson MI: Inhibition of mammary carcinoma growth by retinoidal benzoic acid derivatives. Exp Cell Biol 1988, 56:254-263.

5. Donato LJ, Noy N: Suppression of mammary carcinoma growth by retinoic acid: proapoptotic genes are targets for retinoic acid receptor and cellular retinoic acid-binding protein II signaling. Cancer Res 2005, 65:8193-8199.

6. Liu Y, Lee MO, Wang HG, Li Y, Hashimoto Y, Klaus M, Reed JC, Zhang X: Retinoic acid receptor beta mediates the growth-inhibitory effect of retinoic acid by promoting apoptosis in human breast cancer cells. $\mathrm{Mol}$ Cell Biol 1996, 16:1138-1149. 
7. Seewaldt VL, Kim JH, Caldwell LE, Johnson BS, Swisshelm K, Collins SJ: Alltrans-retinoic acid mediates $\mathrm{G} 1$ arrest but not apoptosis of normal human mammary epithelial cells. Cell Growth Differ 1997, 8:631-641.

8. Sporn MB, Dunlop NM, Newton DL, Smith JM: Prevention of chemical carcinogenesis by vitamin A and its synthetic analogs (retinoids). Fed Proc 1976, 35:1332-1338.

9. Moon RC, Mehta RG: Chemoprevention of experimental carcinogenesis in animals. Prev Med 1989, 18:576-591.

10. Steele VE, Moon RC, Lubet RA, Grubbs CJ, Reddy BS, Wargovich M, McCormick DL, Pereira MA, Crowell JA, Bagheri D, et al: Preclinical efficacy evaluation of potential chemopreventive agents in animal carcinogenesis models: methods and results from the $\mathrm{NCl}$ Chemoprevention Drug Development Program. J Cell Biochem Suppl 1994, 20:32-54.

11. Clarke N, Germain P, Altucci L, Gronemeyer H: Retinoids: potential in cancer prevention and therapy. Expert Rev Mol Med 2004, 6:1-23.

12. Fields AL, Soprano DR, Soprano KJ: Retinoids in biological control and cancer. J Cell Biochem 2007, 102:886-898.

13. Lotan R, Clifford JL: Nuclear receptors for retinoids: mediators of retinoid effects on normal and malignant cells. Biomed Pharmacother 1991, 45:145-156.

14. Xu G, Redard M, Gabbiani G, Neuville P: Cellular retinol-binding protein-1 is transiently expressed in granulation tissue fibroblasts and differentially expressed in fibroblasts cultured from different organs. Am J Pathol 1997, 151:1741-1749.

15. Kuppumbatti YS, Bleiweiss IJ, Mandeli JP, Waxman S, Mira YLR: Cellular retinol-binding protein expression and breast cancer. J Natl Cancer Inst 2000, 92:475-480.

16. Mendelsohn C, Lohnes D, Decimo D, Lufkin T, LeMeur M, Chambon P, Mark M: Function of the retinoic acid receptors (RARs) during development (II). Multiple abnormalities at various stages of organogenesis in RAR double mutants. Development 1994, 120:2749-2771.

17. Mark M, Ghyselinck NB, Chambon P: Function of retinoic acid receptors during embryonic development. Nud Recept Signal 2009, 7:e002.

18. Soprano DR, Teets BW, Soprano KJ: Role of retinoic acid in the differentiation of embryonal carcinoma and embryonic stem cells. Vitam Horm 2007, 75:69-95.

19. Purton LE, Dworkin S, Olsen GH, Walkley CR, Fabb SA, Collins SJ, Chambon P: RARgamma is critical for maintaining a balance between hematopoietic stem cell self-renewal and differentiation. J Exp Med 2006, 203:1283-1293.

20. Li Y, Rosen JM: Stem/progenitor cells in mouse mammary gland development and breast cancer. J Mammary Gland Biol Neoplasia 2005, 10:17-24.

21. Dontu G, Al-Hajj M, Abdallah WM, Clarke MF, Wicha MS: Stem cells in normal breast development and breast cancer. Cell Prolif 2003, 36(Suppl 1):59-72.

22. Molyneux G, Regan J, Smalley MJ: Mammary stem cells and breast cancer. Cell Mol Life Sci 2007, 64:3248-3260.

23. Regan J, Smalley M: Prospective isolation and functional analysis of stem and differentiated cells from the mouse mammary gland. Stem Cell Rev 2007, 3:124-136.

24. Shackleton M, Vaillant F, Simpson KJ, Stingl J, Smyth GK, Asselin-Labat ML, Wu L, Lindeman GJ, Visvader JE: Generation of a functional mammary gland from a single stem cell. Nature 2006, 439:84-88.

25. Stingl J: Detection and analysis of mammary gland stem cells. J Pathol 2009, 217:229-241.

26. Stingl J, Eirew P, Ricketson I, Shackleton M, Vaillant F, Choi D, Li HI, Eaves CJ: Purification and unique properties of mammary epithelial stem cells. Nature 2006, 439:993-997.

27. Lindeman GJ, Visvader JE, Smalley MJ, Eaves CJ: The future of mammary stem cell biology: the power of in vivo transplants. Breast Cancer Res 2008, 10:402, author reply 403.

28. Li Y, Welm B, Podsypanina K, Huang S, Chamorro M, Zhang X, Rowlands T, Egeblad M, Cowin P, Werb Z, Tan LK, Rosen JM, Varmus HE: Evidence that transgenes encoding components of the Wnt signaling pathway preferentially induce mammary cancers from progenitor cells. Proc Nat/ Acad Sci USA 2003, 100:15853-15858.

29. Cho RW, Wang X, Diehn M, Shedden K, Chen GY, Sherlock G, Gurney A, Lewicki J, Clarke MF: Isolation and molecular characterization of cancer stem cells in MMTV-Wnt-1 murine breast tumors. Stem Cells 2008, 26:364-371.

30. Liu BY, McDermott SP, Khwaja SS, Alexander CM: The transforming activity of Wnt effectors correlates with their ability to induce the accumulation of mammary progenitor cells. Proc Natl Acad Sci USA 2004, 101:4158-4163.

31. Lu Y, Bertran S, Samuels TA, Mira-y-Lopez R, Farias EF: Mechanism of inhibition of MMTV-neu and MMTV-wnt1 induced mammary oncogenesis by RARalpha agonist AM580. Oncogene 2010, 29:3665-3676.

32. NIH Tools and Techniques in Mammary Gland Biology - Histological techniques. [http://mammary.nih.gov/tools/histological/Histology/index. html].

33. Kupumbati TS, Cattoretti G, Marzan C, Farias EF, Taneja R, Mira-y-Lopez R: Dominant negative retinoic acid receptor initiates tumor formation in mice. Mol Cancer 2006, 5:12.

34. Sleeman KE, Kendrick H, Ashworth A, Isacke CM, Smalley MJ: CD24 staining of mouse mammary gland cells defines luminal epithelial, myoepithelial/ basal and non-epithelial cells. Breast Cancer Res 2006, 8:R7.

35. Rose-Hellekant TA, Gilchrist K, Sandgren EP: Strain background alters mammary gland lesion phenotype in transforming growth factor-alpha transgenic mice. Am J Pathol 2002, 161:1439-1447.

36. Davie SA, Maglione JE, Manner CK, Young D, Cardiff RD, MacLeod CL, Ellies LG: Effects of FVB/NJ and C57BI/6J strain backgrounds on mammary tumor phenotype in inducible nitric oxide synthase deficient mice. Transgenic Res 2007, 16:193-201.

37. Dontu G, Abdallah WM, Foley JM, Jackson KW, Clarke MF, Kawamura MJ, Wicha MS: In vitro propagation and transcriptional profiling of human mammary stem/progenitor cells. Genes Dev 2003, 17:1253-1270.

38. Moraes RC, Zhang X, Harrington N, Fung JY, Wu MF, Hilsenbeck SG, Allred DC, Lewis MT: Constitutive activation of smoothened (SMO) in mammary glands of transgenic mice leads to increased proliferation, altered differentiation and ductal dysplasia. Development 2007, 134:1231-1242.

39. Asselin-Labat ML, Vaillant F, Shackleton M, Bouras T, Lindeman GJ, Visvader JE: Delineating the epithelial hierarchy in the mouse mammary gland. Cold Spring Harb Symp Quant Biol 2008, 73:469-478.

40. Ginestier $\mathrm{C}$, Hur MH, Charafe-Jauffret E, Monville F, Dutcher J, Brown M, Jacquemier J, Viens P, Kleer CG, Liu S, Schott A, Hayes D, Birnbaum D, Wicha MS, Dontu G: ALDH1 is a marker of normal and malignant human mammary stem cells and a predictor of poor clinical outcome. Cell Stem Cell 2007, 1:555-567.

41. Li Y, Hively WP, Varmus HE: Use of MMTV-Wnt-1 transgenic mice for studying the genetic basis of breast cancer. Oncogene 2000, 19:1002-1009.

42. Vaillant F, Asselin-Labat ML, Shackleton M, Forrest NC, Lindeman GJ, Visvader JE: The mammary progenitor marker CD61/beta3 integrin identifies cancer stem cells in mouse models of mammary tumorigenesis. Cancer Res 2008, 68:7711-7717.

43. Aupperlee MD, Smith KT, Kariagina A, Haslam SZ: Progesterone receptor isoforms $\mathrm{A}$ and $\mathrm{B}$ : temporal and spatial differences in expression during murine mammary gland development. Endocrinology 2005, 146:3577-3588.

44. Shyamala G, Yang X, Cardiff RD, Dale E: Impact of progesterone receptor on cell-fate decisions during mammary gland development. Proc Natl Acad Sci USA 2000, 97:3044-3049.

45. Satoh K, Hovey RC, Malewski T, Warri A, Goldhar AS, Ginsburg E, Saito K, Lydon JP, Vonderhaar BK: Progesterone enhances branching morphogenesis in the mouse mammary gland by increased expression of Msx2. Oncogene 2007, 26:7526-7534.

46. Watson CJ, Khaled WT: Mammary development in the embryo and adult: a journey of morphogenesis and commitment. Development 2008, 135:995-1003.

47. Sternlicht MD: Key stages in mammary gland development: the cues that regulate ductal branching morphogenesis. Breast Cancer Res 2006, 8:201.

48. Lu P, Sternlicht MD, Werb Z: Comparative mechanisms of branching morphogenesis in diverse systems. J Mammary Gland Biol Neoplasia 2006, 11:213-228.

49. Wang YA, Shen K, Wang Y, Brooks SC: Retinoic acid signaling is required for proper morphogenesis of mammary gland. Dev Dyn 2005, 234:892-899.

50. Easwaran V, Pishvaian M, Salimuddin, Byers S: Cross-regulation of betacatenin-LEF/TCF and retinoid signaling pathways. Curr Biol 1999, 9:1415-1418 
51. Shah S, Hecht A, Pestell R, Byers SW: Trans-repression of beta-catenin activity by nuclear receptors. J Biol Chem 2003, 278:48137-48145.

52. Visvader JE: Keeping abreast of the mammary epithelial hierarchy and breast tumorigenesis. Genes Dev 2009, 23:2563-2577.

53. Cheng T, Rodrigues N, Dombkowski D, Stier S, Scadden DT: Stem cell repopulation efficiency but not pool size is governed by p27(kip1). Nat Med 2000, 6:1235-1240.

54. Yilmaz OH, Valdez R, Theisen BK, Guo W, Ferguson DO, Wu H, Morrison SJ: Pten dependence distinguishes haematopoietic stem cells from leukaemia-initiating cells. Nature 2006, 441:475-482.

55. Zhang J, Grindley JC, Yin T, Jayasinghe S, He XC, Ross JT, Haug JS, Rupp D, Porter-Westpfahl KS, Wiedemann LM, Wu H, Li L: PTEN maintains haematopoietic stem cells and acts in lineage choice and leukaemia prevention. Nature 2006, 441:518-522.

56. Dolle P: Developmental expression of retinoic acid receptors (RARs). Nucl Recept Signal 2009, 7:e006

57. Prasad CP, Rath G, Mathur S, Bhatnagar D, Parshad R, Ralhan R: Expression analysis of E-cadherin, Slug and GSK3beta in invasive ductal carcinoma of breast. BMC Cancer 2009, 9:325.

doi:10.1186/bcr2724

Cite this article as: Cohn et al:: RAR 1 control of mammary gland ductal morphogenesis and wnt1-tumorigenesis. Breast Cancer Research 2010 12:R79

\section{Submit your next manuscript to BioMed Central} and take full advantage of:

- Convenient online submission

- Thorough peer review

- No space constraints or color figure charges

- Immediate publication on acceptance

- Inclusion in PubMed, CAS, Scopus and Google Scholar

- Research which is freely available for redistribution

Submit your manuscript at www.biomedcentral.com/submit 